\title{
KETERKAITAN TIPOLOGI DENGAN FUNGSI DAN BENTUK: STUDI KASUS BANGUNAN MASJID
}

\author{
Gatot Suharjanto \\ Architecture Department, Faculty of Engineering, Binus University \\ Jl. K.H. Syahdan No. 9, Palmerah, Jakarta Barat 11480 \\ gatotsuharjanto@binus.edu
}

\begin{abstract}
Besides having a particular function or purpose, a building also has certain characters that generally appear and are accumulated into an image or impression given by anyone who sees the building. Function is a fundamental starting point for all architectural expression. The influence of function on the architecture is quite obvious especially when we observe differences in the use of certain building and how certain activities can create the form of the building. However, is it true that the function and form of the building has any relation with the formation of building classification (typology)? For that reason, this paper discusses a case study of mosque buildings.
\end{abstract}

Keywords: typology, function, shape, buildings, mosques

\begin{abstract}
ABSTRAK
Selain memiliki fungsi atau kegunaan tertentu, sebuah bangunan juga memiliki karakter tertentu yang pada umumnya akan muncul dan terakumulasi menjadi sebuah citra ataupun kesan yang diberikan oleh siapapun kepada bangunan tersebut. Fungsi merupakan titik awal yang mendasar bagi semua expresi arsitektur. Pengaruh fungsi terhadap bentuk arsitektur memang cukup jela,s terlebih ketika kita mengamati perbedaan penggunaan gedung tertentu dan bagaimana aktivitas tertentu dapat menciptakan bentuk tersebut. Namun apakah benar bahwa fungsi dan bentuk bangunan memiliki keterkaitan dengan terbentuknya sebuah klasifikasi bangunan atau dengan istilah yang sering digunakan yaitu tipologi bangunan? Untuk itulah uraian ini akan pembahasan dengan mengambil studi kasus bangunan-bangunan masjid.
\end{abstract}

Kata kunci: tipologi, fungsi, bentuk, bangunan, masjid 


\section{PENDAHULUAN}

Kata tipologi terdiri atas type yaitu berasal dari kata typos (bahasa Yunani), yang bermakna impresi, gambaran, bentuk, jenis atau karakter suatu objek sedangkan logy adalah ilmu yang mempelajari tentang sesuatu, Sehingga tipologi dapat diartikan sebagai ilmu yang mempelajari tentang impresi, gambaran, bentuk, jenis atau karakter dari suatu objek.

Tipologi dapat juga diartikan sebagai sebuah konsep yang memilah sebuah kelompok objek berdasarkan kesamaan sifat-sifat dasar, seperti yang diungkapkan oleh Ching, FDK (1979), bahwa ada kecenderungan untuk mengelompokan unsur-unsur dalam suatu posisi yang random, baik berdasarkan kepada kekompakkan perletakkan, maupun karakteristik visual yang dimiliki. Hal ini diungkapkannya saat mendapatkan hampir dari semua bangunan pada umumnya selalu memasukkan unsur-unsur yang sifatnya berulang seperti kolom dan balok yang berulang-ulang mengikuti modular tertentu.

Sejalan dengan itu Sulistijowati (1991:12), mengatakan bahwa pengenalan tipologi akan mengarah pada upaya untuk mengkelaskan, mengelompokkan atau mengklasifikasikan berdasar aspek atau kaidah tertentu berdasarkan antara lain: (1) fungsi, meliputi penggunaan ruang, struktural, simbolis, dan lain-lain; (2) geometrik, meliputi bentuk, prinsip tatanan, dan lain-lain; (3) langgam, meliputi periode, lokasi atau geografi, politik atau kekuasaan, etnik dan budaya, dan lain-lain.

Berdasarkan kepada seluruh paparan di muka, bisa diambil sebuah makna simpulan dari tipologi arsitektur yaitu bahwa Tipologi merupakan sebuah metode ataupun konsep yang berupaya untuk mengklasifikasikan sebuah objek bangunan atas dasar kondisi dan kesepakatan bagi terciptanya kesamaan bahasa (komunikasi) dengan berdasarkan atas; fungsi, geometrik, langgam, warna, skala, tekstur, bentuk, garis, kebudayaan, sosial-politik dsb

Hal ini berarti ada satu tipe-tipe tertentu dari suatu bangunan yang akan membentuk satu karakter, ciri atau image yang secara "general" dapat dijadikan patokan untuk dapat dikelompokan, seperti warna, skala, tekstur, garis, bentuk, potongan-potongan bidang maupun ruang.

Masjid adalah tempat yang berbentuk fisik bangunan ataupun non fisik bangunan (area terbuka) di mana kegiatan sujud (ibadah) dilakukan disamping kegiatan kegiatan sosial dari sekumpulan jamaah yang terikat akan aturan dan tata cara maupun batasan tertentu dalam Islam.

Masjid dalam perjalanan awalnya hanya merupakan sebuah ruang non fisik yang di dirikan pertama kali oleh Nabi Muhammad (Tahun 622 M) beserta para Sahabat dan pengikutnya sesaat setelah kedatangannya (hijrah) di Madinah. Dengan ruang terbuka yang hanya dibatasi oleh garis batas tanah milik warga Madinah yang diserahkan sebagai tempat pusat kegiatan pergerakan Nabi dan pengikutnya inilah yang kemudian mereka sebut masjid. Seiring perjalanan waktu, dinding pembatas mulai dibuat untuk membedakan aktivitas khusus dan aktivitas publik (Gambar 1).

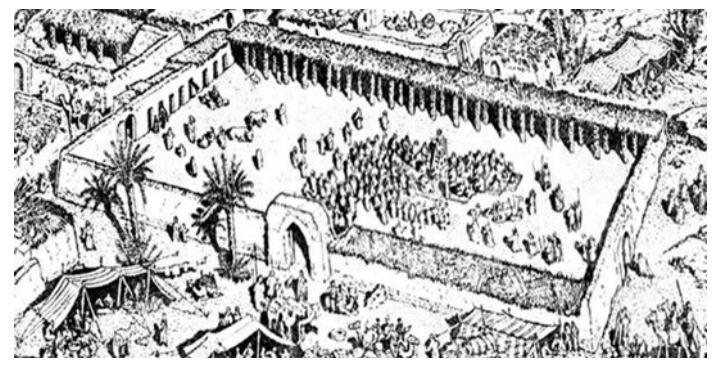

Gambar 1 Rekonstruksi masjid Rasulullah dengan berbagai aktivitas sosial dan semangat keislamannya (Aazam, 2007) 
Selanjutnya, masjid mulai berevolusi dengan berkecenderungan untuk menjadi satu sosok bangunan yang memiliki elemen elemen arsitektur standard berupa lantai, dinding, atap serta bukaan bukaannya. Dari hasil kajian di berbagai negara terhadap perancangan sebuah masjid, didapati berbagai variasi dan kreasi yang sungguh luar biasa. Masjid dibuat dengan teknologi, biaya dan sumber daya yang disesuaikan dengan kondisi regional di mana ia berdiri, tanpa adanya keharusan untuk meletakkan elemen tertentu. Adaptasi dari unsur budaya lokal banyak sekali dimanfaatkan sebagai mana bisa kita lihat dalam Gambar 2 berikut:
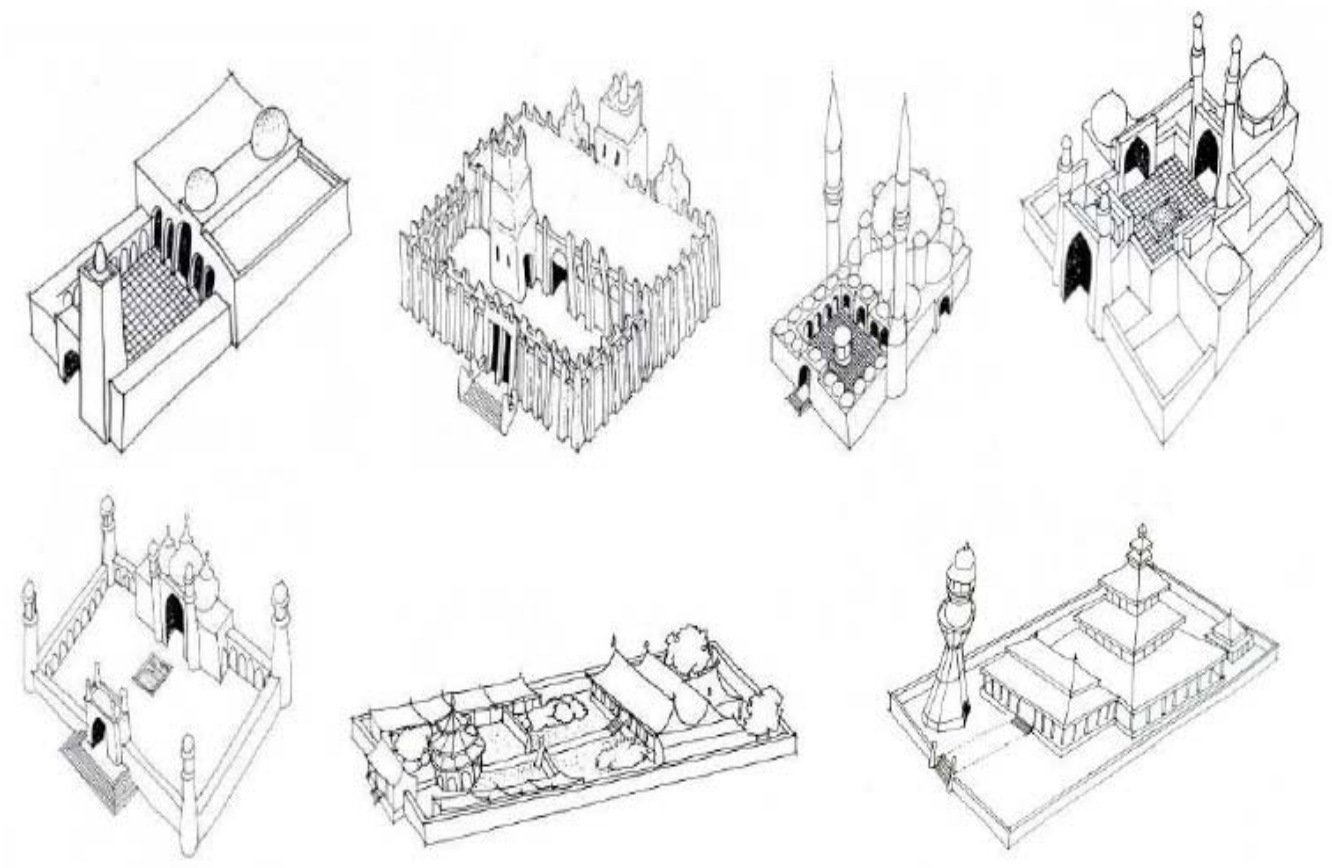

Gambar 2 Berbagai bentuk tipologi masjid di berbagai negara (dari kiri ke kanan), atas: Tipologi masjid di tanah Arab, masjid di Afrika, masjid di Turki dan masjid di Iran, bawah: Tipologi masjid di India, masjid di Cina dan masjid di Asia Tenggara

(Mitchell, 1978)

Saat ini hampir semua orang memberikan satu persepsi yang hampir sama terhadap tipologi masjid. Secara awam orang dapat mengatakan bahwa arsitektur masjid berbentuk dasar kotak, memiliki kubah, ada menaranya, memiliki bukaan bukaan yang lebar, dengan ornamen lengkung menyerupai bentuk bawang dsb. Meski tidak sepenuhnya benar, tapi melalui metode pencarian acak via "google image" dengan kata kunci "masjid", ternyata kemunculan pada tampilan pertama dan kedua dilayar komputer menunjukkan tampilan yang mengandung karakter bentuk dengan unsur unsur tadi (Gambar 3).

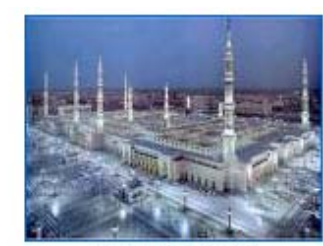

masjid nabawi $1024 \times 768-110 \mathrm{k}-\mathrm{jpg}$ blumewahabi.wordpress.com $[\{0><\} 0\{>$ Lainnya dari
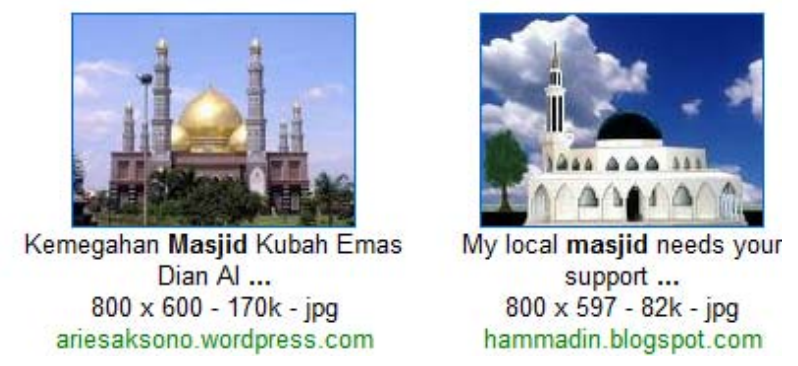

Gambar 3 Gambar “masjid” di Google.com 
Sementara dalam waktu yang bersamaan pencarian gambar masjid dicoba menggunakan kata kunci dalam bahasa inggris, mosque, dan diperoleh hasil seperti yang berikut ini (Gambar 4):
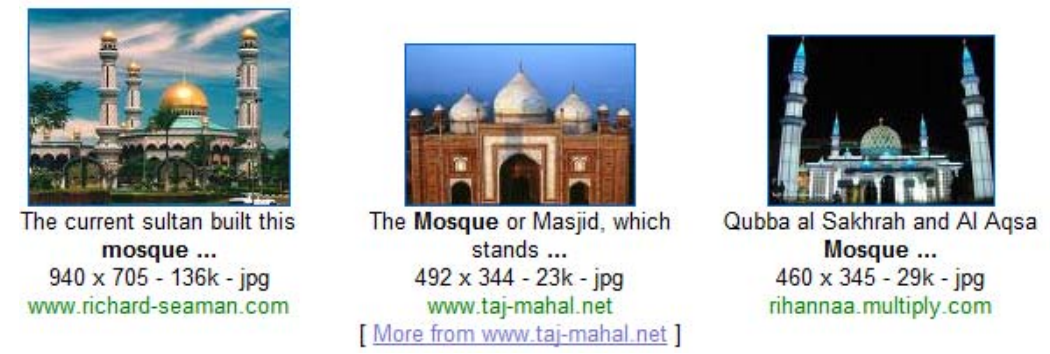

Gambar 4 Gambar "mosque" di Google.com.

Barangkali perlu juga dilihat lagi gambar masjid dengan mencari kata kunci dari bahasa lain lagi, misalnya bahasa Spanyol yaitu mezquita (Gambar 5) dan bahasa Romawi yaitu moschee (Gambar $6)$.
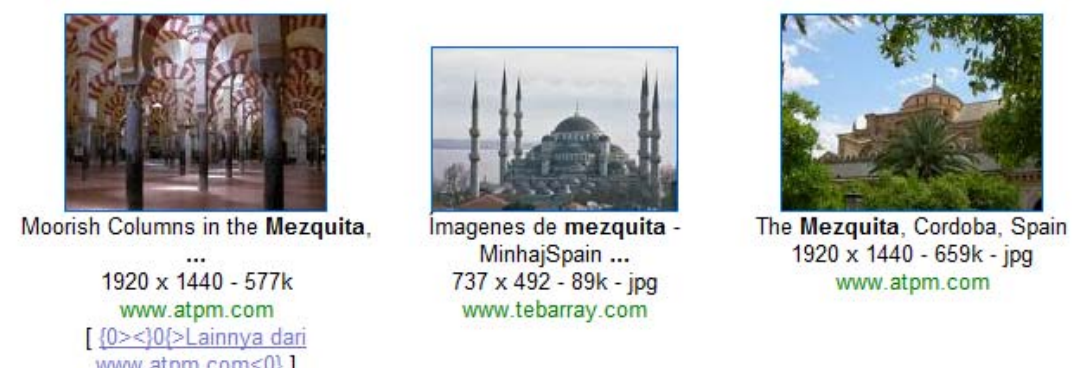

Gambar 5 Gambar “mezquita” di Google.com
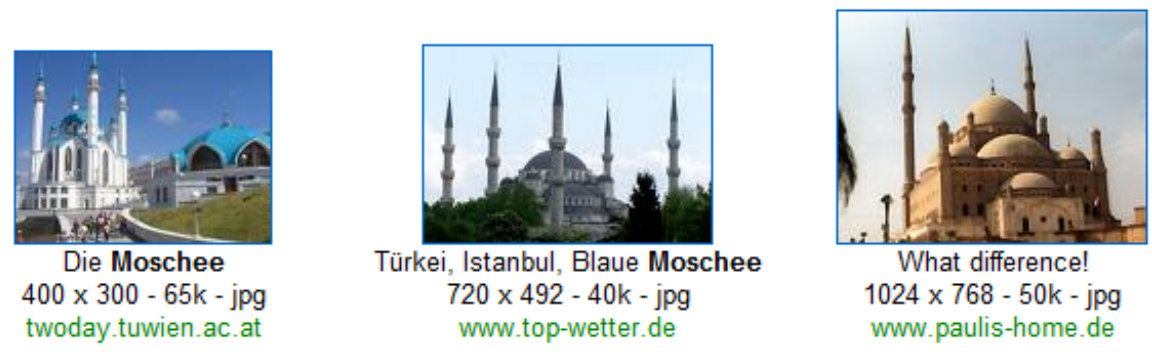

Gambar 6 Gambar “moschee” di Google.com

Lantas, faktor apa yang mempengaruhi tipologi masjid menjadi seperti itu, yaitu rata rata memiliki: (1) menara (baik satu atau lebih); (2) kubah (baik satu atau lebih); (3) elemen lengkung setengah lingkaran, setengah ellips, lengkung lancip dst.; (4) mihrab (tempat imam); (5) gate (gerbang dengan jumlah tunggal maupun lebih dari satu); (6) pagar pembatas? Oleh sebab itu mari kita tinjau aspek-aspek yang barangkali menjadi faktor yang mempengaruhi bentuk mesjid.

\section{METODE}

Tulisan ini merupakan uraian ringkas yang mengupas ciri ciri umum atau tipologi dari bangunan masjid yang dipersepsikan oleh kebanyakan orang di Indonesia, berupa metode deskriptis komparatif berdasarkan penelusuran dari sumber-sumber literatur maupun melalui mesin pencari 
internet. Hasil penelusuran ini hanyalah mencari informasi awal yang secara signifikan tidak dianalisis terlalu dalam, namun cukup untuk digunakan sebagai landasan penelitian lebih lanjut.

\section{HASIL DAN PEMBAHASAN}

Berdasarkan teori yang sudah dipaparkan dimuka, bahwa salah satu penentu tipologi adalah Fungsi dan Bentuk, maka penelusuran dari aspek tersebutlah yang perlu diperhatikan dan diuraikan.

\section{Fungsi Masjid}

Fungsi masjid adalah selain sebagai tempat kaum muslimin beribadah (Habluminallah-ritual ibadah kepada Tuhan) juga merupakan pusat komunitas kaum muslimin (hablumminannas hubungan antar manusia) tempat belajar memahami Islam maupun dakwah. Kegiatan bersama ini berlangsung setiap hari dalam satuan waktu tertentu (rutin) dan umumnya membutuhkan ruangan yang cukup luas serta datar sehingga area lantai ruang masjid bisa dipastikan berbentuk datar. Keharusan atas adanya imam (pemimpin) dan makmum (pengikut imam - lebih dari satu orang dengan barisan "shaff" rapat berpola teratur layaknya sekumpulan manusia yang melakukan upacara bendera) jelas mempengaruhi rancangan denah masjid kearah bentuk sederhana dan optimal yaitu segi empat, sementara keberadaan mimbar sebagai wadah aktivitas imam memberikan elemen tambahan pada denah (mihrab). Orientasi/hadapan yang harus menghadap ke satu arah yaitu ke Mekah dan adanya larangan untuk melintas di depan jamaah serta adanya kebutuhan akan mimbar dan mihrab memberikan konsekwensi logis pada penempatan akses sirkulasi keluar-masuk masjid, yaitu berada pada sisi sisi selain dari area imam. Dengan kata lain, dari bentuk denah yang segi empat tadi, hanya tiga sisi lah yang menjadi akses keluar masuknya manusia ke dalam masjid (Gambar 7).

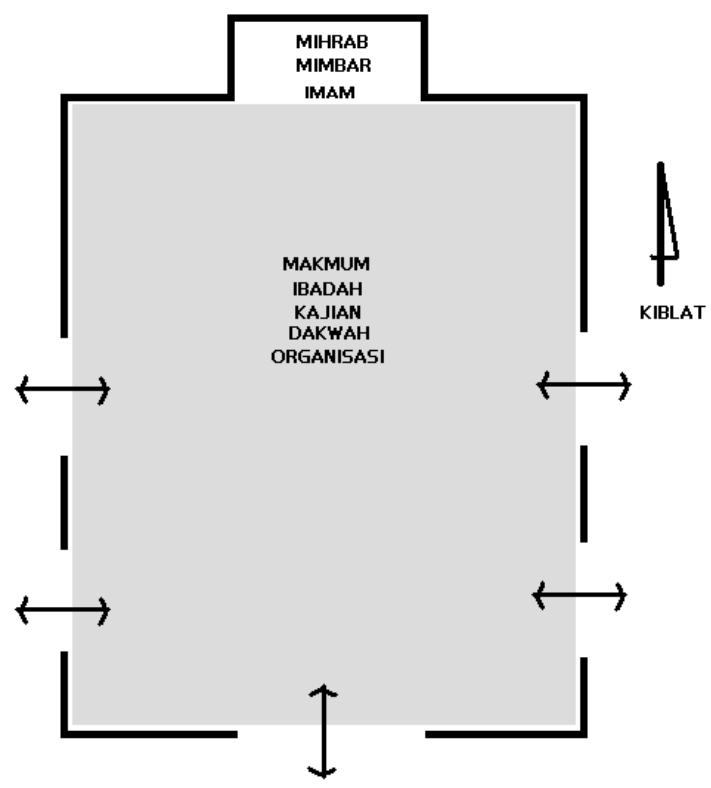

Gambar 7 Denah masjid sesuai fungsinya

Lantas ideologi semacam apa yang kemudian memunculkan bentuk bentuk ornamen semacam lengkungan, kubah, menara, bukaan-bukaan besar, pintu gerbang, pagar dan lain lain, sementara sejak awal masjid tidak terlalu membutuhkan hal itu? 


\section{Elemen Masjid}

\section{Menara}

Menara (Gambar 8) adalah sebuah bentuk yang paling ideal untuk melakukan pemanggilan atau seruan dengan suara lantang dari seorang manusia kepada para jamaah kaum muslimin untuk hadir ke masjid dalam rangka melakukan ibadah rutin. Kembali kepada konsekwensi logis bahwa adanya tempat yang lebih tinggi lebih memungkinkan untuk tersebarnya suara dengan jangkauan yang lebih jauh dari sumber suara. Bentuk-bentuk menara masjid awalnya dapat dilihat pada Gambar 9.
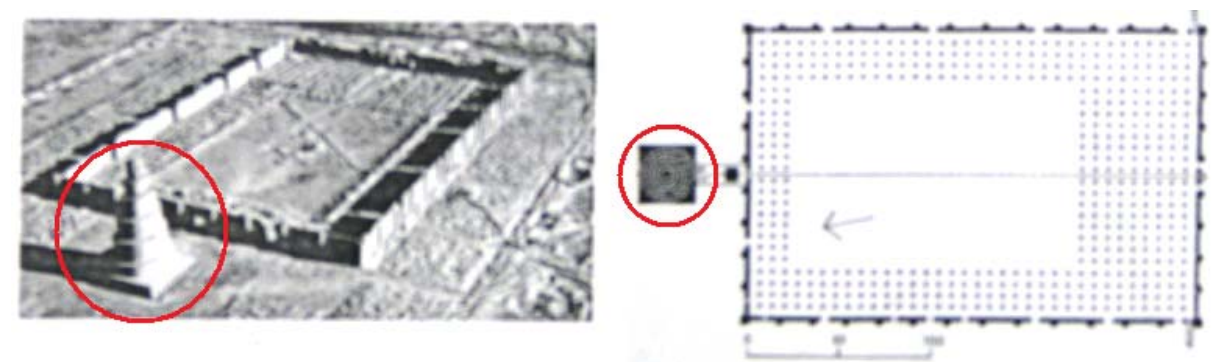

Gambar 8 Menara

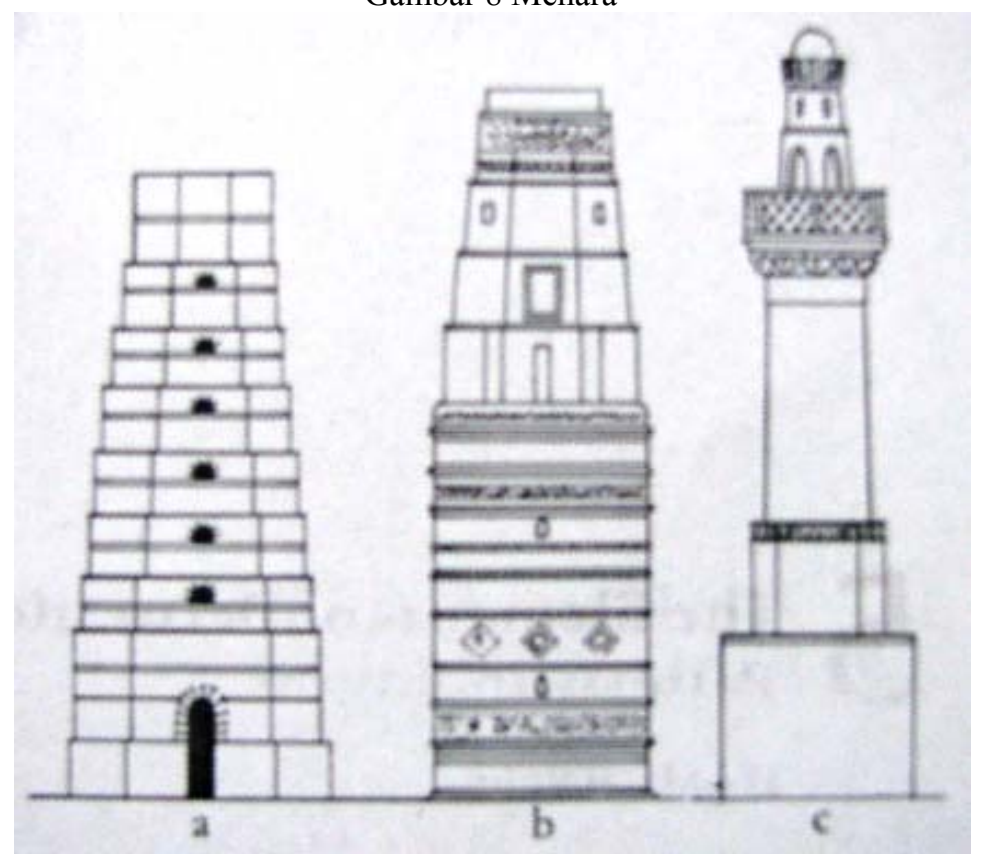

Gambar 9 Menara Masjid pada generasi awal (Aazam, 2007)

\section{Kubah}

Manusia secara alamiah membutuhkan adanya perlindungan dari pengaruh alam, angin, hujan, terik matahari dsb. Demikian pula halnya dengan masjid membutuhkan adanya atap. Sementara kegiatan bersama dalam masjid idealnya adalah seperti lapangan terbuka, tidak terhalang oleh adanya tiang tiang penyangga. Untuk mengakomodir kebutuhan tersebut, sangat beralasan jika selayaknya dibuat atap dengan bentang lebar. Namun teknologi bentang lebar saat itu belumlah ada. Yang ada hanyalah bentuk-bentuk kubah sederhana yang terbuat dari susunan bata untuk menggapai bentang yang tidak terlampau luas (Gambar 10) akibat dari ketidak tersediaan material kayu di sana. Jenis ini banyak ditemui di beberapa daerah di kawasan permukiman Mesopotamia dan Iran. Bentuk ini 
ditemukan pada tahun abad 8 SM. Dengan tuntutan dan kondisi teknologi yang ada saat itulah, betuk kubah adalah pilihan yang paling tepat untuk mencapai tingkat bentang maksimal dibandingkan dengan metode pembuatan atap lainnya. Kemudian ternyata bentuk kubah pun sangat pas untuk keperluan akustik suara, yang darinya lah pantulan suara menjadi terpusat pada ruang tanpa distorsi yang besar.
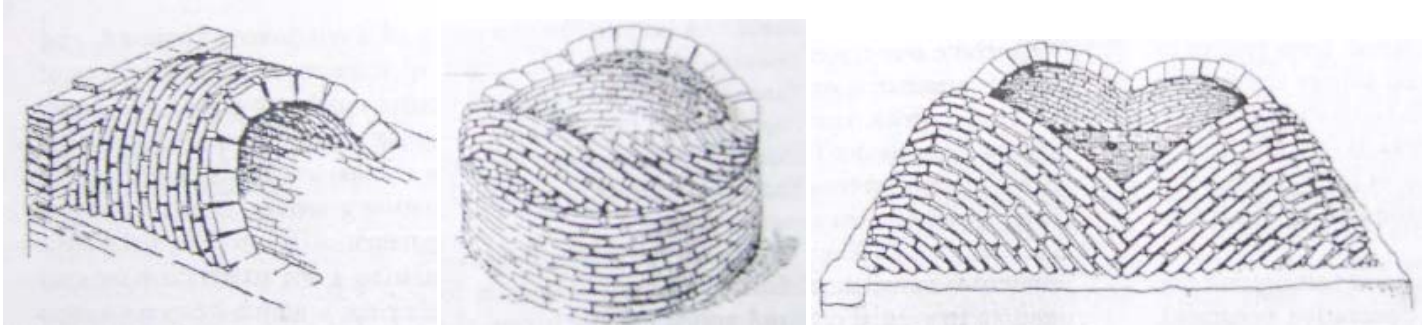

Gambar 10 Bentuk kubah sederhana pada masa lampau

\section{Bukaan (Pintu dan Jendela)}

Sirkulasi keluar dan masuk masjid yang relatif bersamaan secara rutin terjadi setiap lima kali dalam sehari menjadikan kebutuhan akan adanya pintu pintu yang berskala besar. Dan kembali kepada kondisi teknologi yang terbatas saat itulah, bentuk lengkung (Gambar 11) menjadi pilihan tepat sebagai cara untuk mengakomodir bukaan lebar.

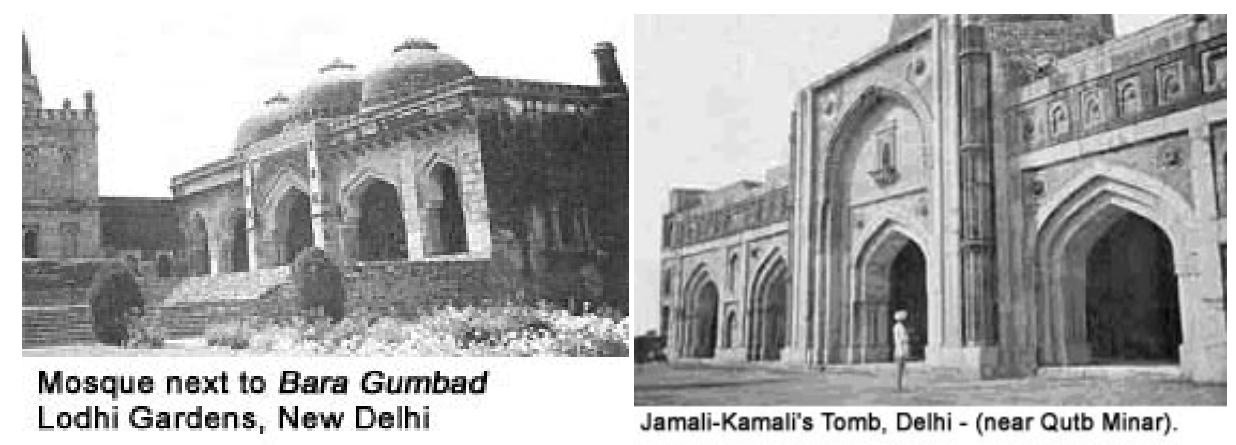

Gambar 11 Bukaan (pintu dan jendela) berbentuk lengkung

\section{PENUTUP}

Dari uraian di atas, bisa disimpulkan bahwa tipologi sangat terkait dengan fungsi dan bentuk bangunan. Sementara bentuk sebetulnya sangat terpengaruh atas perubahan fungsi, sehingga apabila fungsi tidak terlampau banyak berubah, seperti halnya bangunan masjid, kecenderungan untuk memiliki karakter bentuk yang sama akan terus berulang dalam rentang waktu yang lama. Hal ini sejalan dengan konsep form follows function dari arsitek modernis Louiss Sullivan, yang menyatakan bahwa bentuk arsitektur secara rasional dilahirkan dari fungsi atau program ruang tertentu barangkali sangat berlaku atas pengaruh fungsi terhadap tipologi bangunan masjid. 


\section{DAFTAR PUSTAKA}

Aazam, Ziad. (2007). The social logic of the mosque: a study in building typology. Proceedings, 6th International Space Syntax Symposium, İstanbul, Turkey.

Ching, FDK. (1979). Architecture Form, Space and Order. New York: Van Nostrand Reinhold Company.

Mitchell, George. (1978). Architecture of the Islamic World. London: Thames and Hudson.

Sulistijowati, M. (1991). Tipologi Arsitektur pada Rumah Kolonial Surabaya: Dengan Kasus Perumahan Plampitan dan Sekitarnya.

Tulisan tidak dipublikasikan. Surabaya: Pusat Penelitian. 